\title{
Extent of Stem Dieback in Trembling Aspen (Populus tremuloides) as an Indicator of Time-Since Simulated Browsing
}

\author{
Allan W. Carson, ${ }^{1}$ Roy V. Rea, ${ }^{2}$ and Arthur L. Fredeen ${ }^{3}$ \\ Authors are ${ }^{1}$ Undergraduate Student, ${ }^{2}$ Senior Lab Instructor, and ${ }^{3}$ Associate Professor, Ecosystem Science and Management Program, University of \\ Northern British Columbia, Prince George, British Columbia, Canada, V2N 4 Z9.
}

\begin{abstract}
Simulated browsing treatments were imposed on an important browse species of the North American moose (Alces alces L.) to see if the development and extent of subsequent stem dieback in trembling aspen (Populus tremuloides Michx.) could be used to determine the time of browsing during the growing season. Two hundred naturally growing aspen saplings of similar size and form were randomly selected in a 20-ha area near the endowment lands of the University of Northern British Columbia, Prince George, British Columbia, Canada. Plants were randomly assigned to treatment categories so that the apical meristems of 50 plants each were assigned to a control or were clipped on one of the following dates 6 weeks apart: 1 June, 16 July, and 30 August 2005. The leader of each aspen was clipped and dieback was left to progress until the onset of winter dormancy. Our results showed that the earlier the simulated browsing occurs in the growing season, the greater the length of stem dieback, up to the maximum of the subapical axillary node below the point of clipping. The average rate at which dieback progressed varied between treatments and decreased throughout the growing season. Our results suggest that the ratio of the actual length of stem dieback to the overall length of stem between the clip point and the subapical axillary node serves as a good indicator for estimating the time at which aspen meristems have been browsed during the growing season.
\end{abstract}

\section{Resumen}

Se aplicaron tratamientos de ramoneo simulado a una importante especie arbustiva para el alce de Norte América (Alces alces L.), para ver si el desarrollo y la cantidad de muerte descendente de los tallos del "Trembling aspen" (Populus tremuloides Michx.) pudieran ser usados para determinar el periodo de ramoneo durante la estación de crecimiento. En un área de 20 ha, cercana a los terrenos de la Universidad del Norte de Columbia Británica en Prince George, British Columbia, Canadá, se seleccionaron, en forma aleatoria, 200 plántulas de "Aspen” de una población natural, todas de tamaño y forma similar. Las plantas se asignaron aleatoriamente a los tratamientos, de tal forma que los meristemos ápicales de 50 plantas fueron asignados a un control o fueron cortadas en una de las siguientes fechas con seis semanas de separación entre ellas: 1 de junio, 16 de julio, y 30 de agosto del 2005. El tallo principal de cada plántula fue cortado y se dejo que ocurriera la muerte descendente hasta el inicio de la dormancia invernal. Nuestros resultados mostraron que entre más temprano ocurra la simulación del ramoneo en la estación de crecimiento mayor es la longitud de la muerte descendente de los tallos, hasta el máximo del nudo subápical axilar abajo del punto de corte. La tasa promedio a la cual progresó la muerte descendente varió entre tratamientos y disminuyó a través de la estación de crecimiento. Nuestros resultados sugieren que la relación de la longitud actual de la muerte descendente con la longitud del tallo entre el punto de corte y el nudo subápical axilar sirve como un buen indicador para estimar la época en la que los meristemos del "Aspen” han sido ramoneados durante la estación de crecimiento.

Key Words: cattle, clipping, meristem, moose, plant response, stem necrosis

\section{INTRODUCTION}

Deciduous shrubs and trees are an important source of food for wild ungulates such as moose (Alces alces L.; Danell 1982). Although browsing ungulates tend to concentrate foraging efforts less on twigs in summer when aquatics, forbs, and other forage items are plentiful, browsing on stem materials does occur throughout the year (Danell et al. 1994). Free-range cattle are also known to browse twigs during the summer months (Visscher et al. 2006).

Correspondence: Roy V. Rea, Ecosystem Science and Management Program, University of Northern British Columbia, 3333 University Way, Prince George, British Columbia, Canada, V2N 4Z9. Email: reav@unbc.ca

Manuscript received 9 November 2006; manuscript accepted 5 June 2007
Understanding the seasonal use of rangeland plants is integral to assessing how important particular plant species are in the seasonal diet choices of ungulates. Such data can help in determining rangeland quality and carrying capacity, as well as identifying preferred forage items of wild and domestic animals sharing rangelands at specific times of the growing season.

Currently, no method appears to be available for use in approximating the time at which stems are browsed. Consequently, we investigated the utility of using patterns of aspen stem dieback (also referred to as apical dieback or necrosis; Chaar et al. 1997) in response to clipping as a means to estimate when stems are browsed. Our hypothesis was that the total amount of stem dieback observed on dormant stems that had been previously browsed was dependent on the amount of time dieback had to occur during the previous growing season, 
and therefore could serve as an indicator of when stems were browsed. We assumed that dieback progression along a stem was time-dependent and was unrelated to the amount of stem tissue removed by biting or clipping.

\section{STUDY AREA}

The study took place on an approximately 20 -ha area located adjacent to the University of Northern British Columbia endowment lands near Prince George, British Columbia, Canada (lat $53^{\circ} 53^{\prime} \mathrm{N}$, long $122^{\circ} 40^{\prime} \mathrm{W}$ ). The topography is rolling and the site elevation is $780 \mathrm{~m}$ above sea level. The climate is continental and characterized by seasonal extremes with cold winters and warm, moist summers. Mean annual precipitation is approximately $460 \mathrm{~mm}$; snow fall averages approximately $200 \mathrm{~cm}$ and mean annual temperatures range from $1.7^{\circ} \mathrm{C}$ to $5^{\circ} \mathrm{C}$ (Atmospheric Environment Service 1993). The study area was clear cut approximately 15 years prior to the study. Trembling aspen (Populus tremuloides Michx.) is the dominant species on the site. Pioneering species such as willow (Salix spp.), paper birch (Betula papyrifera Marsh.), and alder (Alnus spp.) are also present. Moose and deer (Odocoileus spp.) are both native to the area and use browse species within the study site. Our observations, however, indicate that most of the browsing on aspen in our study area is done by moose (approximately 1.35 moose $\cdot \mathrm{km}^{-2}$; Walker et al. 2006).

\section{METHODS}

In the spring of 2005 , the bite diameters of 50 stems, previously browsed by moose, were measured to obtain a reference for clipping. Subsequently, two hundred unbrowsed aspen saplings of similar size and form within the site were then selected and 50 each were randomly assigned to one of three clipping treatments and a control group. Clipping treatments were applied 6 weeks apart on 1 June, 16 July, and 31 August 2005.

For each clipping treatment, the leader of each individual aspen was clipped at a diameter of $4.0 \mathrm{~mm}$ (following a determination of the average bite point diameter) to simulate browsing by moose. Between 7 and 14 January 2006, the top $50 \mathrm{~cm}$ of all aspens that had been clipped in 2005 was harvested from each plant. A total of 160 stems were recovered from the original 200 individuals; forty individuals were damaged or killed by moose between treatment time and top harvest.

The amount of dieback on each stem was determined by peeling the bark away from the edge of the simulated browse point to the base of the stem to reveal the extent of the necrosis within the underlying tissue. The entire length of stem that could have experienced dieback (typically to the subapical axillary node; sensu Chaar et al. 1997) was considered the dieback potential (DP; Fig. 1). The dieback length (DL) was measured from the simulated browse line to the dieback terminus (the point to which the dieback had actually progressed down the stem; Fig. 1) at 4 locations around the stem circumference and then averaged. The difference between DP and DL was termed the residual length (RL), and was the part of the stem that was healthy, but had the potential for dieback to occur if time allowed. The ratio DL/DP, termed the

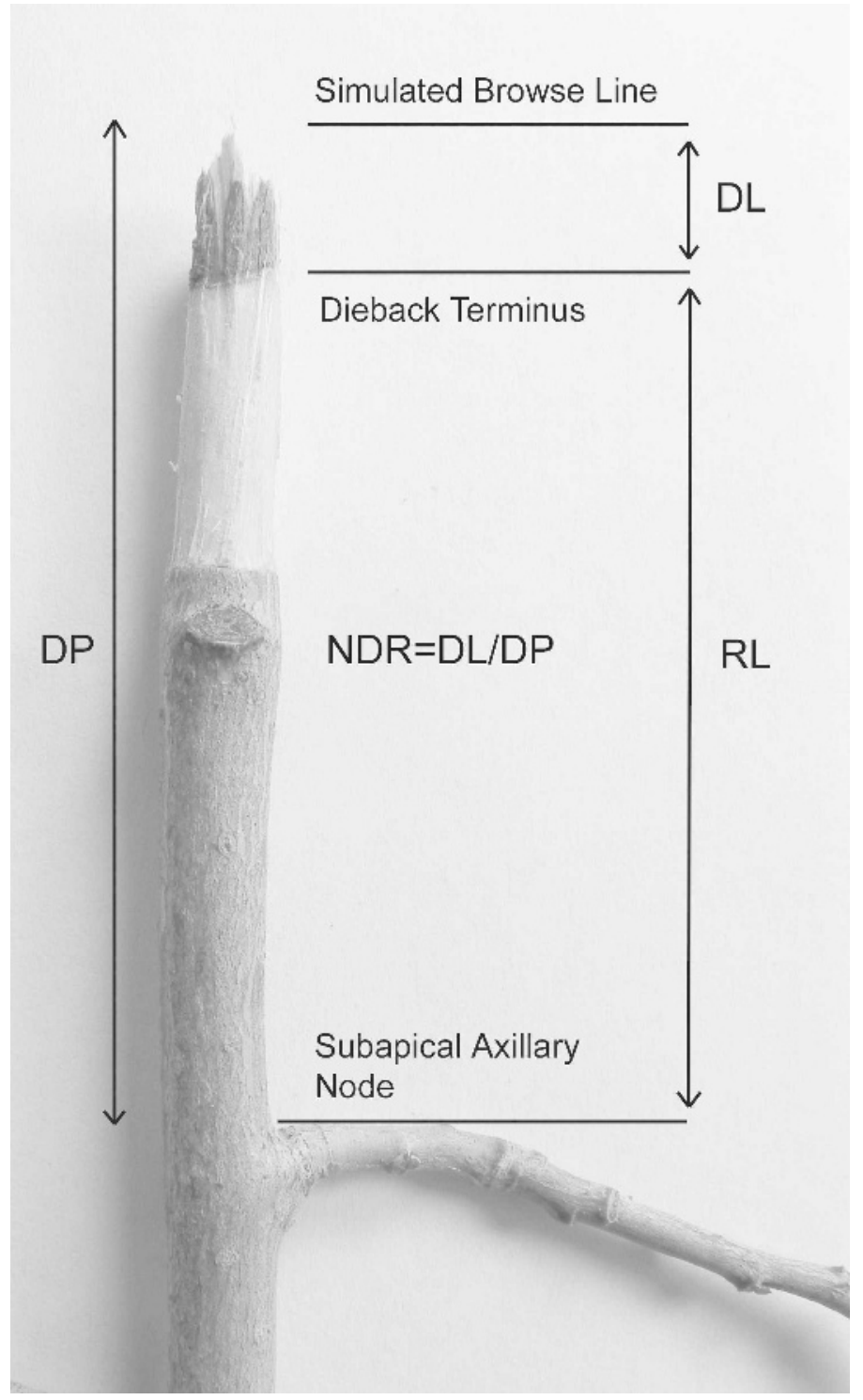

Figure 1. Picture of an aspen stem illustrating the anatomy of stem dieback after browsing depicting: dieback length (DL) measured between the edge of the simulated browse line and the dieback terminus; residual length $(\mathrm{RL})$ measured as the distance between the dieback terminus and the subapical axillary node; and dieback potential (DP) measured between the simulated browse line and the subapical axillary node. The normalized dieback ratio (NDR) is DL/DP.

normalized dieback ratio (NDR; Fig. 1) was used to describe the portion of the DP that experienced dieback. Average rate of dieback $\left(\mathrm{mm} \cdot \mathrm{d}^{-1}\right)$ is the amount of dieback (DL) that occurred over the time between clipping and the onset of winter dormancy.

\section{Statistical Analyses}

We used one-way analysis of variance for unequal sample sizes (ANOVA; Zar 1999) to compare differences in stem dieback, potential dieback, and the normalized dieback ratio between clipping treatments. Homogeneity of variances were tested using a Levene's test (Milliken and Johnson 1984). A Kolmogorov-Smirnov test was used to test assumptions of normality (Zar 1999). Square root transformations (Tabach- 


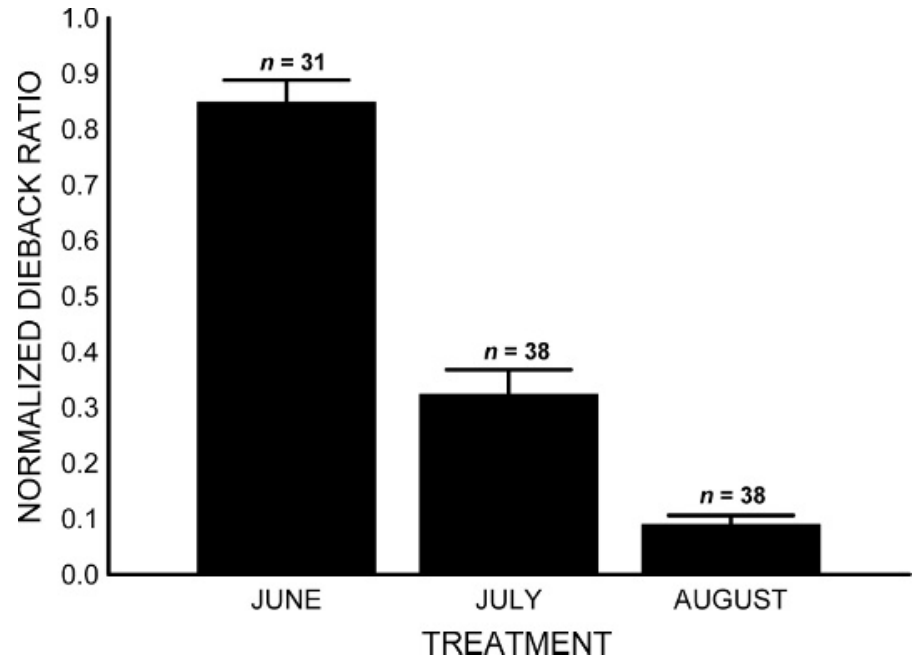

Figure 2. Comparison of the average (+1 SE) normalized dieback ratio for aspen stems subjected to simulated browsing at three different times (1 June, 16 July, and 31 August) during the 2005 growing season. All treatments are significantly different from one another $(P<0.05)$.

nick and Fidell 1996) were applied to normalize our rate and normalized dieback ratio data. Tukey's honestly significant difference (HSD) test for unequal sample sizes (Zar 1999) was used for posthoc comparisons among treatments when a significant effect was detected. All ANOVAs were performed using Statistica (StatSoft 2005). We used linear regression to determine the relationship between the average rate of dieback and the dieback potential. Regression equations were computed using graphics software (DeltaGraph v.5.0.1; SPSS Inc, and Red Rock Software, Salt Lake City, UT).

\section{RESULTS}

The absolute length of stem dieback (DL) after simulated browsing was significantly affected by time of simulated browsing and was largest for plants clipped earliest in the growing season $\mathrm{F}_{2,104}=42.858, P<0.001$ between all three clipping trials. Because dieback could potentially extend all of the way back to the subapical axillary node (see Fig. 1), but was not consistent among stems, we normalized the dieback length (NDR). The NDR was different among all three clipping trials and was smallest for those plants clipped later in the year $\mathrm{F}_{2,104}=105.494, P<0.001$ (Fig. 2).

The average rate of dieback $\left(\mathrm{mm} \cdot \mathrm{d}^{-1}\right)$ was greatest for plants clipped in June $\mathrm{F}_{2,104}=13.772, P<0.001$, but was not significantly different among plants clipped in July and August. Similarly, there was an increase in the average rate of dieback with an increase in potential length for dieback (DP; Fig. 3). Stems with long dieback potentials ( $\left.\mathrm{Y}=0.0087 \mathrm{x}-0.0171, R^{2}=0.995\right)$ had higher average dieback rates than those with short dieback potentials $\left(\mathrm{Y}=5 \mathrm{E}^{-05} \mathrm{x}+0.0959, R^{2}=0.0028\right.$; Fig. 3$)$.

\section{DISCUSSION}

Our findings indicate that several differences in stem dieback occur and are measurable among stems clipped at different

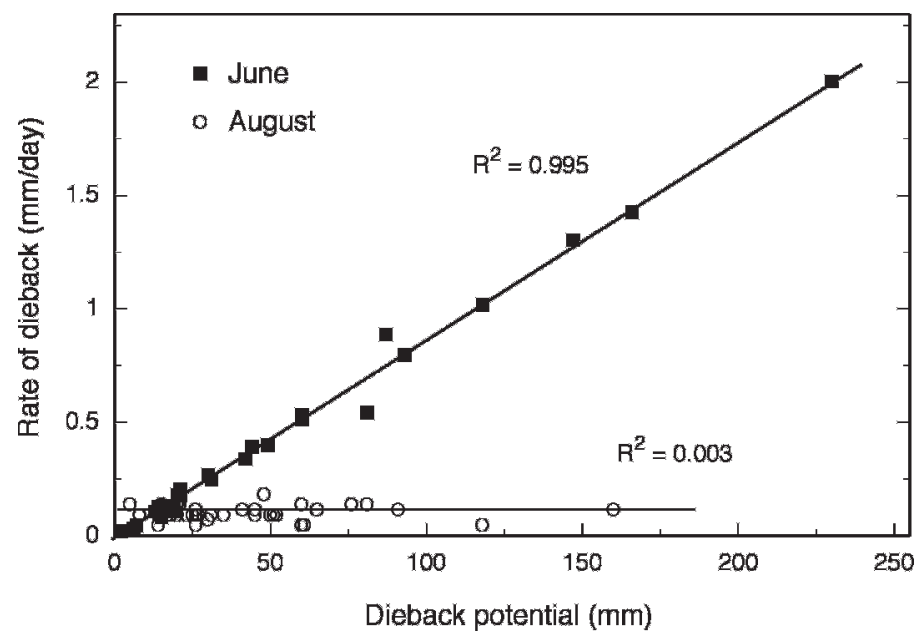

Figure 3. The relationship between the average rate of dieback and the dieback potential (length between the simulated browse line and the subapical axillary node). Note: Days to dormancy is the number of days from the time of clipping treatment until 23 September 2005 (estimated dormancy initiation; see text).

times of the growing season. The attributes that show the most significant differences are the length of dieback and residual length. The dieback potential and length of dieback are significant in calculating the "normalized dieback ratio" (NDR). This ratio appears to be a reasonable method for approximating the time during the growing season in which shoots are browsed. Because studies have shown that clipping stems to simulate browsing can produce the same response as natural browsing (Haukioja and Huss-Danell 1997), it is reasonable to assume that both clipping and natural browsing affect leaf and shoot characteristics in similar ways.

The length of dieback was dependent on the timing of the clipping event during the growing season and the length between the point of clipping and the subapical axillary node (DP). It appears that the time at which the clipping event occurred determined the amount of time available for dieback to progress down the stem until the onset of winter dormancy (about 23 September; personal communication, Jos V. Hage, Art Knapp Plant Land, Prince George, BC, 21 September 2006). Although more severe tissue removal occurs during treatment, brush-cutting appears to have a similar influence on cambium dieback in young aspen (Bell et al. 1999); cambium dieback is more pronounced in the stumps of summer- vs. fall-cut aspens.

Stems clipped in June had the greatest amount of time for the dieback to progress down the stem, followed by July, and then August where the amount of time for dieback to occur was 92 days less than plants clipped in the June trial. Although stems clipped earlier generally revealed the greatest amount of dieback when compared with late-clipped stems, dieback was clearly moderated by the amount of tissue between the clip point and the subapical axillary node. This suggests that the greater the distance that dieback must travel to reach the subapical axillary node (DP), the more quickly it progresses (Fig. 3). Regardless of the dieback potential, stem dieback progressed towards the subapical axillary node within a given 
period of time. The average rate of dieback progression, therefore, differs between stems with different dieback potentials. Therefore, it seems that the length of dieback is not a good indicator for determining when stems are browsed. This is simply because the length of dieback is dependent on the dieback potential. Stems with different dieback potentials browsed at the same time during the growing season show different average rates of dieback progression and therefore different lengths of dieback. For the same reason, residual length is not a good predictor for determining the time at which browsing occurred-it shares an inverse relationship with the dieback length.

The most accurate predictor for determining when aspen stems are browsed appears to come from calculating the normalized dieback ratio, which is the ratio of the length of dieback to the potential dieback on a given stem. Regardless of how quickly dieback progresses down the stem, or how far it has to travel from the clip point to reach the subapical axillary node, the normalized dieback ratio represents how much stem has died back relative to the total amount of tissue wherein dieback is able to occur.

The "normalized dieback ratio" measurements appear to roughly correspond with the percentage of the growing season that dieback has to progress and appears to be useful for approximating the time during which the browsing event occurs. For example, on average, stems clipped on 1 June reached a normalized dieback ratio of approximately $85 \%$. The interval between 1 June and 23 September also comprises approximately $85 \%(114 / 135)$ of the growing season (1 May to 23 September) in northern British Columbia. Shoots clipped at the end of August, on the other hand, reached an average normalized dieback ratio of $10 \%$, and 30 August to 23 September represents $16 \%(22 / 135)$ of the growing season. Stems characterized by reaching $100 \%$ of their dieback potential are most likely to have been browsed at the very beginning of the growing season or sometime prior to the initiation of stem metabolic activities in spring. Conversely, stems showing no signs of stem dieback when analyzed in winter are stems likely damaged during the current dormant period; dormant stems appear incapable of initiating dieback until stem dormancy is broken in spring (personal observations).

Although the phenomenon of dieback appears to be present in other species (e.g., Amelanchier alnifolia Nutt., Acer douglasii Hook., Betula papyrifera Marshal; personal observations) at the study site, factors such as the average rate of dieback and the variation in dieback potential are likely to vary between species and could affect the utility of this technique for estimating the time of browsing for various species. Because aspen carbon allocation strategy involves a relatively early switch from carbon production to carbon storage (Lieffers et al. 2001), the reduction in the average rate of dieback might occur earlier in the growing season for aspen compared to other shrubs and trees used by ungulates. If the carbon allocation strategy of another plant involved a reduction in the average rate of dieback later in the growing season, higher rates of dieback progression are likely to occur for longer periods and the estimated time to complete dieback could be reduced. Further experimentation might reveal some differences in patterns of dieback between various species. Furthermore, conducting clipping trials over the entire growing season at smaller intervals (e.g., every 2 weeks) could also reveal some finer detail in patterns of dieback progression within and between species.

\section{MANAGEMENT IMPLICATIONS}

Our results indicate that the normalized dieback ratio, when assessed during plant dormancy, can serve as an indicator of when in the previous growing season aspen stems were browsed. This ratio can be easily obtained from individual stems in the field by removing the bark just below a bite point on a stem and dividing the dieback length by the overall dieback potential of the stem. The quotient obtained corresponds closely with, and therefore approximates, the amount of growing season that transpired between the occurrence of browsing and the onset of plant dormancy.

Although we only investigated the dynamics of stem dieback on aspen in one study area, the technique we developed likely has some application for assessing the timing of browse on aspen and other plant species in other regions. We suggest that this technique could be useful for naturalists and rangeland managers as a tool to help evaluate patterns of animal behavior and nutrition or the impacts of browsing on the physiology and seasonal nutrient dynamics of plants used as food by both wild and domestic ungulates.

\section{ACKNOWLEDGMENTS}

The authors would like to thank Adam Kantakis and Dorianna Hoekstra for their assistance with the clipping trials. We thank Aaron Skoblenick for volunteering his time during the harvest of aspen stems and John Orlowsky and Steve Storch of the Enhanced Forest Lab at UNBC for providing supplies and general assistance. We also thank Dr Phil Burton and two anonymous reviewers for the valuable suggestions on earlier drafts of this manuscript.

\section{LITERATURE CITED}

Atmospheric Environment Service. 1993. Canadian Climate Normals 1961-1990 British Columbia. Downsview, Canada: Canadian Climate Program, Atmospheric Environment Service, Environment Canada. Available at: http://www. climate.weatheroffice.ec.gc.ca/climate_normals/index_1961_1990_e.html. Accessed 30 July 2007.

Bell, F. W., D. G. Pitt, A. E. Morneault, and S. M. Pickering. 1999. Response of immature trembling aspen to season and height of cut. Northern Journal of Applied Forestry 16:108-114.

Chaar, H., F. Colin, and G. Leborgne. 1997. Artificial defoliation, decapitation of the terminal bud, and removal of the apical tip of the shoot in sessile oak seedlings and consequences of subsequent growth. Canadian Journal of Forest Research 27:1614-1621.

DanelL, K. 1982. Shoot growth of Betula pendula and B. pubescens in relation to moose browsing. Alces 18:197-209.

Danell, K., R. Bergstrom, and L. Edenius. 1994. Effects of large mammalian browsers on architecture, biomass, and nutrients of woody plants. Journal of Mammalogy 75:833-844.

Haukioja, K. E., and K. Huss-Danell. 1997. Morphological and chemical responses of mountain birch leaves and shoots to winter browsing along a gradient of plant productivity. Ecoscience 4:296-303. 
Lieffers, V. J., S. M. Landhausser, and E. H. Hogg. 2001. Is the wide distribution of aspen a result of its stress tolerance?; 13-15 June 2000; Grand Junction, Colorado. Fort Collins, CO: Rocky Mountain Research Station Publications. $13 \mathrm{p}$.

Milliken, G. A., And D. E. Johnson. 1984. Analysis of messy data. Volume I. Designed experiments. New York, NY: Van Nostrand Reinhold. 473 p.

StatSoft Inc. 2005. Statistica [data analysis software system]. Version 7.1. Tulsa, OK: Statsoft, Inc.

TabaChnick, B. G., and L. S. Fidell. 1996. Using multivariate statistics. 3rd ed. New York, NY: Harper Collins College Publishers. 880 p.
Visscher, D. R., E. H. Merrill, D. Fortin, and J. L. Frair. 2006. Estimating woody browse availability for ungulates at increasing snow depth. Journal of Forest Ecology and Management 222:348-354.

Walker, A. D. B., D. C. Heard, V. Michelfelder, and G. S. Watts. 2006. Moose density and composition around Prince George, British Columbia. Prince George, British Columbia, Canada: British Columbia Ministry of Environment, Final Report for Forests for Tomorrow 2914000. 23 p.

ZAR, J. H. 1999. Biostatistical analysis. 4th ed. Saddle River, NJ: Prentice Hall. $736 \mathrm{p}$. 